\title{
THE EFFECT OF GROWTH BIOSTIMULATORS AND HERBICIDE ON THE CONTENT OF SUGARS IN TUBERS OF EDIBLE POTATO (SOLANUM TUBEROSUM L.)
}

\author{
BARANOWSKA, A.*-MYSTKOWSKA, I. \\ Department of Agriculture, Pope John II State School of Higher Education in Biala Podlaska, \\ Sidorska 95/98, 21-500 Biała Podlaska, Poland \\ *Corresponding author \\ e-mail: a.baranowska@dydaktyka.pswbp.pl; phone: +48-83-344-99-08 \\ (Received $8^{\text {th }}$ Jan 2019; accepted $14^{\text {th }}$ Feb 2019)
}

\begin{abstract}
Currently, new solutions are searched for in crop production that will provide plants with favourable conditions for growth and development, ensuring high consumer quality of harvested products further to being friendly for the environment. One of the most important features negatively affecting the quality of consumer quality of edible potato tubers is the increased content of total sugars and especially reducing sugars. Therefore, the aim of the experiment was to determine the impact of five methods of care using the growth biostimulators and herbicide on the content of total sugars and reducing sugars in tubers of three edible potato varieties. A series of three-year field experiments was carried out in the years 2015-2017 in the region of Eastern Poland $\left(52^{\circ} 02^{\prime} \mathrm{N} ; 23^{\circ} 07^{\prime} \mathrm{E}\right)$. The experiments were assumed with random sub-blocks method in three repetitions, on light acidic soil. The examined factors were: I factor three early edible potato varieties (Owacja, Bellarosa, Vineta), II factor - five methods of care using growth biostimulators: GreenOk - Universal Pro and Asahi SL and their combination with Avatar 293 ZC herbicide. As a result of the studies, it was concluded that genetic features of the cultivated varieties, as well as methods of care applied in the experiment did not have a significant impact on the content of total sugars and reducing sugars in tubers of potato. The value of these characteristics substantially depended only on the course of thermal-precipitation conditions in the given years of research. Significantly higher content of total sugars (an average $0.74 \%$ ) was shown by the tubers harvested in a warm and dry growing season of the year 2015, whilst the highest content of reducing sugars in tubers was recorded in a cool, wet growing season of 2017 (an average of $0.39 \%$ ).
\end{abstract}

Keywords: Solanum tuberosum L., anti-nutritional components, GreenOk-Uniwersal Pro, Asahi SL, Avatar 293 ZC

\section{Introduction}

Potato (Solanum tuberosum L.) is one of the most important cultivated plants not only in Poland (potato consumption in Poland amounts to approximately $100 \mathrm{~kg} /$ person/year) but it also constitutes the basis of diet of a growing number of people worldwide - it is grown in about 160 countries. Current consumption of fresh potatoes has a decreasing trend, however the processed products have become more and more popular; especially fried potatoes (French fries, crisps), dried, pasteurized, blanched, as well as sliced and subjected to an initial heat treatment (Camire et al., 2009; Ezekiel et al., 2013; Grużewska et al., 2016).

The nutritional value of potato results mainly from the chemical composition of the tubers. The components that are of large importance in human nutrition include: starch, complete protein, fibre, vitamins and minerals. Contrary to the prevailing opinion, Potato tubers are low-calorie and easily digestible. The caloric value of the tubers is approximately $50-90 \mathrm{kcal} / 100 \mathrm{~g}$ and is comparable to the energy value of apples (54 
$\mathrm{kcal})$ or milk (62 kcal) and is 10 times less than the caloric value of chocolate (563 kcal) (Navarre et al., 2009; Zarzecka et al., 2013; Zgórska, 2013; Wegner et al., 2015).

In the edible potato production, particular attention should be paid to the contents of sugars: total (glucose + fructose + sucrose) and reducing sugars (glucose + fructose), which are important features indicating the usefulness of tubers intended for direct human consumption, frying, or drying. In the weight of fresh tubers intended for direct consumption and processing, the total sum of sugars should not exceed $1 \%$ and reducing sugars $0.5 \%$. Whist within the potatoes used for the production of French fries and crisps the content of reducing sugars should not be greater than respectively 0.25 and $0.15 \%$. Increased content of total sugars $(>1 \%)$ gives the tubers sweet taste and causes them to darken faster, which results in deterioration of the culinary quality of tubers (Cropp et al., 2000; Finaly et al., 2003; Zgórska and Sowa-Niedziałkowska, 2005; Storey, 2007; Grudzińska et al., 2014).

In potato tubers, the increased content of reducing sugars is especially undesirable and dangerous to human health (Hebeisen et al., 2005). Their negative impact is revealed during the preparation of potato products, fried foods (French fries, crisps), as well as baked or roasted ones (at temperature $>120^{\circ} \mathrm{C}$ ). Reducing sugars with amino acids are involved in Maillard's reactions (this is a series of chemical reactions, which occur frequently under the influence of heat between amino acids and reducing sugars). They adversely affect the colour, taste and smell of food products, as well as give rise to acrylamide $\left(\mathrm{C}_{3} \mathrm{H}_{5} \mathrm{NO}\right)$ very harmful for our health - a compound with neurotoxic and carcinogenic action. According to Mojska et al. (2008) and Żyżlewicz et al. (2010) in French fries and crisps there may be significant content of acrylamide (from 50 to 2400$2600 \mu \mathrm{g} / \mathrm{kg}$ ), whilst French fries prepared at home tend to have a higher content of acrylamide than those prepared in industrial conditions.

The use of raw material with low $(0.1-0.2 \%)$ concentration of reducing sugars is considered the primary factor limiting the formation of acrylamide toxicity (Amrein et al., 2004; Biedermann-Brem et al., 2003; De Wilde et al., 2006; Wójcik-Stopczyńska et al., 2012).

The content of total sugars and reducing sugars in tubers of potatoes depends on numerous factors, such as a genetic factor of the cultivated varieties, climatic conditions, as well as the applied agrotechnical treatments (Grudzińska and Zgórska, 2008, 2010; Grudzińska et al., 2014; Zarzecka et al., 2017).

In plant production, including also in potato agro-technology, all sorts of preparations friendly to agro-eco-systems have been increasingly applied, which are referred to as biostimulators. They restrict the use of agrochemicals and thus contribute to the development of sustainable crop production methods (Du Jardin, 2012; Calvo et al., 2014; Baranowska et al., 2017). Biostimulators are synthetic or natural preparations which enhance stimulating of the life processes of plants and increase the resistance of plants to stress conditions (Ziosi et al., 2013; Matyjaszczyk, 2015). Their chemical composition includes a whole range of bioactive compounds such as humus substances, algae, microorganisms, mineral elements, vitamins, amino acids, nitrophenols, cytokinins, auxins and other substances classified as plant hormones (Bulgari et al., 2015).

However, the possibility of using biostimulators in farming practice is not yet fully discovered, and in Poland so far there have been no scientific studies on the impact of GreenOk-Uniwersal Pro on more important qualitative features of potato tubers. Therefore, the aim of the experiment was to determine the impact of the five methods of 
care using growth biostimulators and herbicide on the content of total sugars and reducing sugars in tubers of three edible potato varieties.

\section{Materials and methods}

\section{Experiment and plant material}

The three-year field experiment was executed in the years of 2015-2017 in the region of Eastern Poland, in Biała Podlaska municipality $\left(52^{\circ} 02^{\prime} \mathrm{N} ; 23^{\circ} 07^{\prime} \mathrm{E}\right)$, in the Lublin Voivodeship on light, acidic soil (Fig. 1). The soil was characterized by a very high content of assimilable forms of phosphorus and potassium and high to very high form of magnesium.

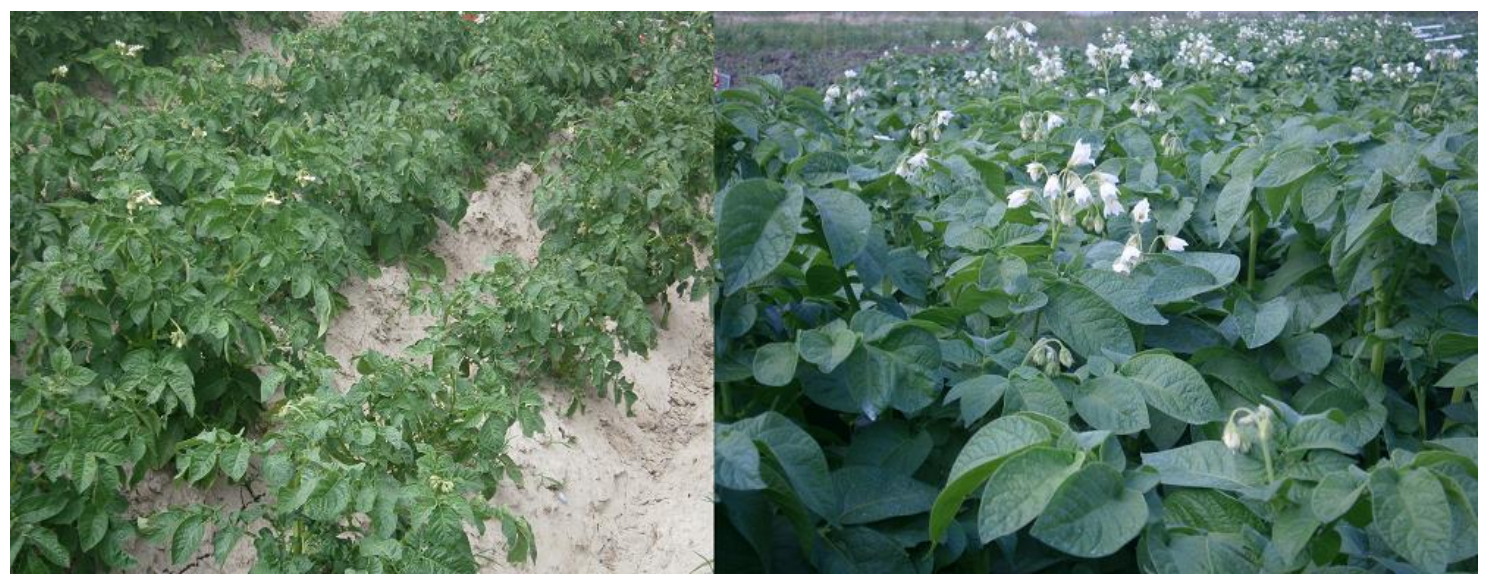

Figure 1. One of the experiment objects

The experiment took place in the split-plot system in three repetitions. The impact of the two factors was studied (Table 1).

Table 1. Factors of the experiment

I. Factor - Three early edible potato cultivars: Bellarosa, Owacja, Vineta

II. Factor - Five methods of treatment with the application of growth biostimulators and herbicide:

1. Standard object - mechanical treatment (without biostimulators and herbicide).

2. From sprouting of potato plants - mechanical treatment and after sprouting - GreenOK Universal-PRO bioactivator, three times to leaves: at a dose of $0.10 \mathrm{dm}^{3} \mathrm{ha}^{-1}$ (phase BBCH 13-19) + $0.15 \mathrm{dm}^{3} \mathrm{ha}^{-1}$ (phase BBCH 31-35) + $0.15 \mathrm{dm}^{3} \mathrm{ha}^{-1}$ (phase BBCH 51-55).

3. From sprouting of potato plants - mechanical treatment, and after sprouting - Asahi SL bioactivator, three times to leaves at a dose of $0.50 \mathrm{dm}^{3} \mathrm{ha}^{-1}$ (phase BBCH 13-19) +0.50 $\mathrm{dm}^{3} \mathrm{ha}^{-1}$ (phase BBCH 31-35) + 0.50 $\mathrm{dm}^{3} \mathrm{ha}^{-1}$ (phase BBCH 51-55).

4. From sprouting - mechanical treatment, and after the final shaping of ridges and just before sprouting Avatar $293 \mathrm{ZC}$ herbicide at a dose of $1.5 \mathrm{dm}^{3} \mathrm{ha}^{-1}$ (phase BBCH 00-05). After sprouting - three applications of GreenOK Universal-PRO bioactivator at a dose of $0.10 \mathrm{dm}^{3} \mathrm{ha}^{-1}$ (phase BBCH 13-19) $+0.15 \mathrm{dm}^{3} \mathrm{ha}^{-1}$ (phase BBCH 31-35) $+0.15 \mathrm{dm}^{3} \mathrm{ha}^{-1}$ (phase BBCH 51-55).

5. From sprouting - mechanical treatment, and after the final shaping of ridges before sprouting of potato plants - Avatar $293 \mathrm{ZC}$ herbicide at a dose of $1.5 \mathrm{dm}^{3} \mathrm{ha}^{-1}$ (phase BBCH 00-05). 
The characteristics of potato varieties and preparations used in the experiment have been presented in Tables 2 and 3.

Table 2. Characteristics of varieties of potatoes grown in the experiment. (Source: Plant Breeding and Acclimatization Institute - National Research Institute, Poland 2015)

\begin{tabular}{c|c|c|c}
\hline Variety & $\begin{array}{c}\text { Year of inscription to } \\
\text { the variety register }\end{array}$ & Breeder of variety & $\begin{array}{c}\text { Usefulness of varieties for food } \\
\text { processing }\end{array}$ \\
\hline Bellarosa & 2006 & $\begin{array}{c}\text { Europlant, Pflz. GmbH, } \\
\text { Germany }\end{array}$ & Cooked products, French fries \\
\hline Owacja & 2006 & $\begin{array}{c}\text { PMHZ Strzekęcino, } \\
\text { Poland }\end{array}$ & Puree, pancakes, cooked products \\
\hline Vineta & 1999 & $\begin{array}{c}\text { Europlant, Pflz. GmbH, } \\
\text { Germany }\end{array}$ & $\begin{array}{c}\text { Canned goods, frozen goods, } \\
\text { salads, cooked products }\end{array}$ \\
\hline
\end{tabular}

Table 3. Characteristics of preparations used in the experiment. (Source: Information disclosed by agents' manufacturers)

\begin{tabular}{c|c}
\hline Name of preparation & Content of active substances \\
\hline $\begin{array}{c}\text { Avatar 293 ZC } \\
\text { herbicide }\end{array}$ & Clomazone $60 \mathrm{~g} \mathrm{dm}^{3}(5.13 \%)$, metribuzin $233 \mathrm{~g} \mathrm{dm}^{3}(20.64 \%)$ \\
\hline $\begin{array}{c}\text { GreenOK Universal-PRO } \\
\text { bioactivator }\end{array}$ & $\begin{array}{c}\text { Humus substances } \geq 20 \mathrm{~g} \mathrm{dm}^{3},(\mathrm{NPK} 0.13-0.09-0.7), \text { dry mass } 22 \mathrm{~g} \mathrm{dm}^{3}, \\
\text { humidity } 96 \%, \text { organic substances 3\%, pH 7-9 }\end{array}$ \\
\hline $\begin{array}{c}\text { Asahi SL } \\
\text { bioactivator }\end{array}$ & $\begin{array}{c}\text { Sodium para-nitrophenolate } 3 \mathrm{~g} \mathrm{dm}^{3}(0.3 \%), \text { sodium orto-nitrophenolate } \\
2 \mathrm{~g} \mathrm{dm}^{3}(0.2 \%), \text { sodium 5-nitroguaiacolate } 1 \mathrm{~g} \mathrm{dm}^{3}(0.1 \%)\end{array}$ \\
\hline
\end{tabular}

During each year of the experiment, in autumn, the manure fertilization at a dose of $25 \mathrm{t} \mathrm{ha}^{-1}$ and phosphatic fertilization P: $44.0 \mathrm{~kg} \mathrm{ha}^{-1} \mathrm{~kg}$ and potassium $\mathrm{K}: 124.5 \mathrm{~kg} \mathrm{ha}^{-1}$ were applied, and in spring - fertilization with nitrogen at a dose of $\mathrm{N}: 100 \mathrm{~kg} \mathrm{ha}^{-1}$. Tubers of potato were planted in the second decade of April (in 2015 and 2016) and the third decade of April (in 2017). Treatments for protection against pests (diseases and pests) were used in accordance with the recommendations of the plant protection. The plantation was protected by applying spraying with the following insecticides: Actara $25 \mathrm{WG}$ (thiamethoxam $250 \mathrm{~g} \mathrm{~kg}^{-1}$ ) at a dose of $0.08 \mathrm{~kg} \mathrm{ha}^{-1}$, Calypso $480 \mathrm{SC}$ (thiacloprid $480 \mathrm{~g} \mathrm{dm}^{3}$ ) at a dose of $0.1 \mathrm{dm}^{3} \mathrm{ha}^{-1}$ and fungicides: Copper Max New 50 WP (copper - $500 \mathrm{~g} \mathrm{~kg}^{-1}$ ) at a dose of $2.0 \mathrm{~kg} \mathrm{ha}^{-1}$, Dithane Neo Tec $75 \mathrm{WG}$ (mancozeb $750 \mathrm{~g} \mathrm{~kg}^{-1}$ ) at a dose of $2.0 \mathrm{~kg} \mathrm{ha}^{-1}$. Tuber collections were carried out in the phase of technological maturity.

\section{Chemical analysis methods}

In order to perform chemical analyses of all experimental objects, the tubers from 10 randomly selected plants of potato were sampled (with the exception of the marginal plants). Chemical analyses were performed in three repetitions for each combination of the experiment (90 tests in total). The content of reducing sugars (glucose + fructose) and total sugars (total sugars) were marked in the fresh tuber mass not selected by means of the method of Schoorl-Luff (Krełowska-Kułas, 1993). The results were expressed as percentage of fresh mass. 


\section{Statistical analysis}

Results of research were statistically elaborated by means of the analysis of variance (one-way and two-way Analysis of Variance ANOVA). The significance of the variation sources was studied through test $F$ of Fisher-Snedecor, and the assessment of significance of differences at the significance level 0.05 between the compared averages using multiple compartments of Tukey (post hoc test).

\section{Weather conditions}

Weather data came from The Weather Station of the Cultivars Research Centre (COBORU) in Słupia Wielka and were prepared for the Experimental Station of the Evaluation of Varieties in Cicibór Duży, localized within $6 \mathrm{~km}$ from Biała Podlaska. The weather conditions in growing seasons of 2015-2017 were described on the background of the multi-year period 1981-2010 based on deviations of average monthly air temperature $\left({ }^{\circ} \mathrm{C}\right)$ and total precipitation $(\mathrm{mm})$ and of hydrothermal Sielianinov coefficient (Chereszkowicz, 1979; Skowera, 2014).

The precipation-thermal conditions during the research were varied (Table 4). The total rainfall in the year 2015 reached approx. $63 \mathrm{~mm}$ lower than average rainfall during the multi-year period (1981-2010), while the average temperature was about $1.1^{\circ} \mathrm{C}$ higher than the average long-term air temperature. The biggest deficiency of precipitation was specific for the months of June, July and August. The hydrothermal Sielaninov coefficient $(K=0.99)$ indicates that the growing season of the year 2015 was a dry season. During the execution of the experiment, the moistest and coolest growing season was in 2017. In this season, the rainfall was higher by $74 \mathrm{~mm}$ from the average rainfall from the respective period of the multiannual period, and hydrothermal Sielianinov coefficient was the highest in relation to the rest of the years of research and was 1.50. In 2016, during the period of the largest potato demand for precipitation, the conditions of thermal runoff were more favourable compared to the growing season of 2015 and 2017 (Table 4).

\section{Results and discussion}

One of the most important characteristics that determine the usefulness of potato tubers for direct consumption as well as for processing is the content of total sugars and reducing sugars, which in fresh tuber mass should not exceed 1\% (Grudzińska et al., 2016).

As a result of the executed research, it was found that the content of total sugars in tubers of potato was on average $0.659 \%$ while reducing sugars $0.321 \%$ (Tables 5 and 6 ). The methods of care applied in the experiment, as well as the genetic features of the varieties, did not have a significant impact on the content of total sugars and reducing sugars in tubers of potato. The value of these characteristics depended on the course of thermal-precipitation conditions in the relevant years of research (Tables 5 and 6 ).

Treatment methods using growth biostimulators and herbicide (object 2-5) have contributed to a slight increase of the content of total sugars and reducing sugars compared to the control object that uses only mechanical treatment (without growth biostimulators and herbicide) (object 1) (Tables 5 and 6). Also, Trawczyński (2014) after the application of amino acid biostimulators in the cultivation of potatoes did not note their significant impact on the content of reducing sugars in tubers. Similar test 
results were obtained also by Maciejewski et al. (2007) by applying foliar feeding of potato plants with Asahi SL and SL Atonik biostimulators. Furthermore, RudzińskaMękal (2000) has proved that the growth biostimulators caused a significant increase in the content of reducing sugars in tubers of potato, which may have resulted from inhibition of the biosynthesis of oligo-and polysaccharides due to the decrease in the concentration of potassium in the tubers of potato.

Table 4. Meteorologic conditions according to the Research Centre for Cultivar Testing (COBORU) in Stupia Wielka Poland

\begin{tabular}{|c|c|c|c|c|c|c|c|}
\hline \multirow{2}{*}{ Study year } & \multicolumn{7}{|c|}{ Deviations from the long-term (1981-2010) mean } \\
\hline & IV & $\mathbf{V}$ & VI & VII & VIII & IX & IV-IX \\
\hline \multicolumn{8}{|c|}{ Rainfall (mm) } \\
\hline 2015 & +1 & +32 & -36 & -21 & -60 & +21 & -63 \\
\hline 2016 & 0 & -37 & +18 & +51 & -39 & -42 & -49 \\
\hline 2017 & +27 & -19 & +40 & +1 & -26 & +51 & +74 \\
\hline \multicolumn{8}{|c|}{ Air temperature $\left({ }^{\circ} \mathrm{C}\right)$} \\
\hline 2015 & +0.4 & -1.1 & +0.1 & +0.8 & +3.7 & +2.4 & +1.1 \\
\hline 2016 & +1.8 & +1.1 & +1.8 & +1 & +0.8 & +2.5 & +1.5 \\
\hline 2017 & -0.2 & -0.1 & +1.4 & -0.3 & +2 & +2 & +0.8 \\
\hline \multicolumn{8}{|c|}{ *Sielianinov hydrothermal coefficient $(K)$} \\
\hline 2015 & 1.43 & 2.28 & 0.59 & 0.80 & 0.11 & 1.66 & 0.99 \\
\hline 2016 & 1.19 & 0.47 & 1.53 & 1.97 & 0.48 & 0.26 & 1.00 \\
\hline 2017 & 2.68 & 0.93 & 1.97 & 1.24 & 0.66 & 2.37 & 1.50 \\
\hline
\end{tabular}

*Sielianinov hydrothermal coefficient $(K)$ - formula as in research methodology;

**Month's classification according to: Chereszkowicz (1979) and Skowera (2014): extremely dry $K \leq 0.4$, very dry $0.4<K \leq 0.7$, dry $0.7<K \leq 1.0$, quite dry $1.0<K \leq 1.3$, optimal $1.3<K \leq 1.6$, quite humid $1.6<K \leq 2.0$, humid $2.0<K \leq 2.5$, very humid $2.5<K \leq 3.0$, extremely humid $K>3.0$

In the studies of Gugała et al. (2013) and Sawicka and Pszczółkowski (2005), the applied herbicides, as well as their mixtures did not have a significant impact on the content of sugars in tubers, however, they caused a slight increase in the content of total sugars and reducing sugars. In contrast, Zarzecka et al. (2017) have shown that herbicides: Plateen 41.5 WG (metribuzin + flufenacet) and Racer 250 EC (fluorochloridone) significantly increased the content of total sugars, and herbicide Plateen 41.5 WG increased the content of reducing sugars. Zarzecka and Gugała (2018) after applying herbicide Sencor WG 70 (metribuzin) and growth regulator Asahi SL have found a significant increase in the content of total sugars and reducing sugars in tubers of potato.

Also, the potato varieties cultivated in the study did not differ significantly in terms of discussed quality features. The varieties were characterised by a similar concentration of total sugars - an average from 0.635 to $0.681 \%$ and reducing sugars, on average from 0.314 to $0.345 \%$ (Tables 5 and 6 ), what is confirmed in studies carried out by Sawicka and Pszczółkowski (2005), who found no significant effect of the genetic characteristics of varieties on the content of total sugars and reducing sugars. However, close relationship of the sum of sugars and reducing sugars in cultivated tubers of potato was recorded in the works of Jarych (2004), Zgórska and Grudzinska (2012) and Bhattacharjee et al. (2014). In studies of Maciejewski et al. (2007) after application of biostimulators Asahi SL and Atonik SL, the variety Ditta resulted in the 
reduction of the content of reducing sugars, while the variation of Satina gathered more of them.

Table 5. The average content of total sugars in tubers of potato, \% of fresh mass, depending on the methods of treatment and years of research

\begin{tabular}{c|c|c|c|c|c|c|c}
\hline \multirow{2}{*}{$\begin{array}{c}\text { Methods of } \\
\text { treatments* }\end{array}$} & \multicolumn{3}{|c|}{ Cultivar } & \multicolumn{3}{c|}{ Years } \\
\cline { 2 - 7 } & Bellarosa & Owacja & Vineta & $\mathbf{2 0 1 5}$ & $\mathbf{2 0 1 6}$ & $\mathbf{2 0 1 7}$ & \\
\hline $\mathbf{1}$ & 0.626 & 0.632 & 0.660 & 0.717 & 0.607 & 0.594 & 0.639 \\
$\mathbf{2}$ & 0.631 & 0.669 & 0.683 & 0.738 & 0.626 & 0.620 & 0.661 \\
$\mathbf{3}$ & 0.641 & 0.665 & 0.684 & 0.740 & 0.630 & 0.621 & 0.664 \\
$\mathbf{4}$ & 0.640 & 0.667 & 0.675 & 0.743 & 0.622 & 0.616 & 0.661 \\
$\mathbf{5}$ & 0.639 & 0.677 & 0.702 & 0.767 & 0.637 & 0.615 & 0.673 \\
\hline Mean & $0.635^{\mathrm{a}}$ & $0.662^{\mathrm{a}, \mathrm{b}}$ & $0.681^{\mathrm{b}}$ & $0.741^{\mathrm{c}}$ & $0.624^{\mathrm{d}}$ & $0.613^{\mathrm{d}}$ & 0.659 \\
\hline \multicolumn{7}{c}{ Year $F(2,80.33)=150.51, p=0.00000^{* *}$} \\
Cultivar $F(2,85.22)=3.07, p=0.05159$ \\
\hline
\end{tabular}

${ }_{\mathrm{a}, \mathrm{b}, \mathrm{c}, \mathrm{d}}$ Different letter in the index indicates statistically significant variation

${ }^{*}$ As in the research methodology:

1. Standard object (without biostimulators and herbicide)

2. GreenOK Universal-PRO $0.10 \mathrm{dm}^{3} \mathrm{ha}^{-1}+0.15 \mathrm{dm}^{3} \mathrm{ha}^{-1}+0.15 \mathrm{dm}^{3} \mathrm{ha}^{-1}$

3. Asahi SL $0.50 \mathrm{dm}^{3} \mathrm{ha}^{-1}+0.50 \mathrm{dm}^{3} \mathrm{ha}^{-1}+0.50 \mathrm{dm}^{3} \mathrm{ha}^{-1}$

4. Avatar $293 \mathrm{ZC} 1.5 \mathrm{dm}^{3} \mathrm{ha}^{-1}+$ GreenOK Universal-PRO $0.10 \mathrm{dm}^{3} \mathrm{ha}^{-1}+0.15 . \mathrm{dm}^{3} \mathrm{ha}^{-1}+0.15 \mathrm{dm}^{3} \mathrm{ha}^{-1}$

5. Avatar $293 \mathrm{ZC} 1.5 \mathrm{dm}^{3} \mathrm{ha}^{-1}$

${ }^{* *}$ Significant difference

Table 6. The average content of reducing sugars in tubers of potato, $\%$ of fresh mass, depending on the methods of treatment and years of research

\begin{tabular}{|c|c|c|c|c|c|c|c|}
\hline \multirow{2}{*}{$\begin{array}{l}\text { Methods of } \\
\text { treatments* }\end{array}$} & \multicolumn{3}{|c|}{ Cultivar } & \multicolumn{3}{|c|}{ Years } & \multirow{2}{*}{ Mean } \\
\hline & Bellarosa & Owacja & Vineta & 2015 & 2016 & 2017 & \\
\hline 1 & 0.323 & 0.285 & 0.299 & 0.214 & 0.322 & 0.370 & 0.302 \\
\hline 2 & 0.354 & 0.311 & 0.314 & 0.229 & 0.347 & 0.403 & 0.326 \\
\hline 3 & 0.347 & 0.310 & 0.320 & 0.226 & 0.342 & 0.409 & 0.326 \\
\hline 4 & 0.350 & 0.316 & 0.328 & 0.244 & 0.341 & 0.409 & 0.331 \\
\hline 5 & 0.351 & 0.296 & 0.310 & 0.229 & 0.342 & 0.387 & 0.319 \\
\hline Mean & 0.345 & 0.304 & 0.314 & $0.228^{\mathrm{a}}$ & $0.339^{\mathrm{b}}$ & $0.395^{\mathrm{c}}$ & 0.321 \\
\hline \multicolumn{8}{|c|}{$\begin{array}{l}\text { Year } F(2,81.44)=371.97, p=0.0000 * * \\
\text { Cultivar } F(2,85.33)=2.97, p=0.05639 \\
\text { Methods } F(4,130)=0.55, p=0.70018\end{array}$} \\
\hline
\end{tabular}

a,b,c Different letter in the index indicates statistically significant variation

*As in the research methodology:

1. Standard object (without biostimulators and herbicide)

2. GreenOK Universal-PRO $0.10 \mathrm{dm}^{3} \mathrm{ha}^{-1}+0.15 \mathrm{dm}^{3} \mathrm{ha}^{-1}+0.15 \mathrm{dm}^{3} \mathrm{ha}^{-1}$

3. Asahi SL $0.50 \mathrm{dm}^{3} \mathrm{ha}^{-1}+0.50 \mathrm{dm}^{3} \mathrm{ha}^{-1}+0.50 \mathrm{dm}^{3} \mathrm{ha}^{-1}$

4. Avatar $293 \mathrm{ZC} 1.5 \mathrm{dm}^{3} \mathrm{ha}^{-1}+$ GreenOK Universal-PRO $0.10 \mathrm{dm}^{3} \mathrm{ha}^{-1}+0.15 . \mathrm{dm}^{3} \mathrm{ha}^{-1}+0.15 \mathrm{dm}^{3} \mathrm{ha}^{-1}$

5. Avatar $293 \mathrm{ZC} 1.5 \mathrm{dm}^{3} \mathrm{ha}^{-1}$

${ }^{* * *}$ Significant difference 
In the studies of Gugała et al. (2013) and Sawicka and Pszczółkowski (2005), the applied herbicides, as well as their mixtures did not have a significant impact on the content of sugars in tubers, however, they caused a slight increase in the content of total sugars and reducing sugars. In contrast, Zarzecka et al. (2017) have shown that herbicides: Plateen 41.5 WG (metribuzin + flufenacet) and Racer $250 \mathrm{EC}$ (fluorochloridone) significantly increased the content of total sugars, and herbicide Plateen 41.5 WG increased the content of reducing sugars. Zarzecka and Gugała (2018) after applying herbicide Sencor WG 70 (metribuzin) and growth regulator Asahi SL have found a significant increase in the content of total sugars and reducing sugars in tubers of potato.

Also, the potato varieties cultivated in the study did not differ significantly in terms of discussed quality features. The varieties were characterised by a similar concentration of total sugars - an average from 0.635 to $0.681 \%$ and reducing sugars, on average from 0.314 to $0.345 \%$ (Tables 5 and 6 ), what is confirmed in studies carried out by Sawicka and Pszczółkowski (2005), who found no significant effect of the genetic characteristics of varieties on the content of total sugars and reducing sugars. However, close relationship of the sum of sugars and reducing sugars in cultivated tubers of potato was recorded in the works of Jarych (2004), Zgórska and Grudzinska (2012) and Bhattacharjee et al. (2014). In studies of Maciejewski et al. (2007) after application of biostimulators Asahi SL and Atonik SL, the variety Ditta resulted in the reduction of the content of reducing sugars, while the variation of Satina gathered more of them.

The implemented statistical calculations have shown that changing weather conditions prevailing in the years of research substantially modified the content of total sugars and reducing sugars in tubers of potato.

The largest total sugar content - an average of $0.741 \%$ was characterized by tubers harvested in 2015, in which during the period from June to August there was a high deficit of precipitation and air temperature in August (before the harvest of tubers) was higher by $3.7^{\circ} \mathrm{C}$ from the average multiannual temperature (Tables 4 and 5). While most reducing sugars - an average of $0.395 \%$ were recorded in 2017 , when the lowest air temperature and rainfall compared to the other years occurred (Tables 4 and 6). These results are consistent with the research of Gugała et al. (2013) and Zarzecka et al. (2017), who reported a significant effect of diverse weather conditions on the content of total sugars and reducing sugars in tubers of potato. Also according to other authors, Rodriguez et al. (2010), Murniece et al. (2011) and Brazinskiene et al. (2014), the content of sugars in tubers of potato is not stable and is subject to significant changes in individual years of research.

Sawicka and Pszczółkowski (2005) noted the highest content of total sugars and reducing sugars in the growing season with the most intense sunlight and rainfall. According to Grudzińska et al. (2014), a decisive influence on the content of reducing sugars in the tubers of potato is triggered by air temperature and total precipitation for ten days before harvesting and during the time of harvesting tubers. The authors, by studying 268 potato varieties over the course of fourteen years, found that the higher the air temperature and rainfall deficiency before harvest tubers, the less content of reducing sugars in tubers; whilst Frydecka-Mazurczyk and Zgórska (2002) stated that the potatoes, which before the harvest experienced autumn overcooling, collected reducing sugars more intensely. According to Nourian et al. (2003), this may be due to the activity of the enzyme which catalyses sucrose to glucose and fructose. 
An in-depth analysis revealed a significant effect of interaction of weather conditions and genetic features of varieties on the content of total sugars and reducing sugars in edible potato tubers (Table 7).

Bellarosa variety cumulated substantially less total sugars than the remaining varieties in humid and cool growing season of 2017, whilst in the favourble growing season of 2016, less total sugars were gathered by the tubers of Owacja variety.

In the season of 2017 also a significant effect of genetic features of varieties was reported on the content of reducing sugars. The majority of reducing sugars was cummulated by the tubers of Bellarosa variety, whilst the least -tubers of Owacja variety. No substantial differences in terms of the discussed features were noted in the warm and dry growing season of 2015 (Table 7).

Table 7. Impact of weather conditions on the average content of sugars in fresh potato tuber mass, considering genetic features of varieties (\%) (in-depth analysis)

\begin{tabular}{c|c|c|c|c|c|c}
\hline \multirow{3}{*}{ Cultivar } & \multicolumn{3}{|c|}{ Total sugars } & \multicolumn{3}{c}{ Reducing sugars } \\
\cline { 2 - 6 } & \multicolumn{3}{|c|}{ Year } & \multicolumn{3}{c}{ Year } \\
\cline { 2 - 6 } & $\mathbf{2 0 1 5}$ & $\mathbf{2 0 1 6}$ & $\mathbf{2 0 1 7}$ & $\mathbf{2 0 1 5}$ & $\mathbf{2 0 1 6}$ & $\mathbf{2 0 1 7}$ \\
\hline Bellarosa & $0.740^{\mathrm{a}}$ & $0.639^{\mathrm{b}}$ & $0.528^{\mathrm{d}}$ & $0.230^{\mathrm{a}}$ & $0.348^{\mathrm{b}}$ & $0.457^{\mathrm{d}}$ \\
Owacja & $0.737^{\mathrm{a}}$ & $0.599^{\mathrm{c}}$ & $0.651^{\mathrm{b}}$ & $0.230^{\mathrm{a}}$ & $0.333^{\mathrm{b}}$ & $0.348^{\mathrm{b}}$ \\
Vineta & $0.747^{\mathrm{a}}$ & $0.635^{\mathrm{b}}$ & $0.661^{\mathrm{b}}$ & $0.225^{\mathrm{a}}$ & $0.336^{\mathrm{b}}$ & $0.381^{\mathrm{c}}$ \\
\hline \multirow{3}{*}{ Anova results } & Cultivar: $F(2,126)=23.64, p=0.0000$ & \multicolumn{2}{c|}{ Cultivar: $F(2,126)=30.13, p=0.0000$} \\
& Year: $F(2,126)=226.54, p=0.0000$ & \multicolumn{2}{c}{ Year: $F(2,126)=470.20, p=0.0000$} \\
& Cultivar xYear $: F(4,126)=33.39, p=0,0000$ & Cultivar $x$ Year: $\mathrm{F}(4,126)=19.66, p=0.0000$ \\
\hline
\end{tabular}

a,b,c,d Indicates a homogeneous group (the same letter indicates no significant differences between the averages)

\section{Conclusions}

Currently, an increasing interest in agricultural practice and teachings has been inspired by preparations referred to as growth biostimulators. Therefore, it is very important to familiarize oneself with their impact on the more important quality characteristics of crops, including potato, which occupies an important place in human diet and which has been one of the most frequently cultivated plants (in the global crop production it occupies the fourth place after wheat, rice and maize).

The content and quality of biological substances included in the chemical composition of potato decide about the dietary value of tubers. In tubers, however, there can be substances, whose increased content affects the consumer quality. The priority size of the tubers for food processing is the content of total sugars and reducing sugars. Understanding the impact of agricultural science treatments on the value of these features is a challenge for research not only in Poland but also on the international level.

In own studies, the treatment methods using growth biostimulators as well as cultivation of potato varieties do not have a significant impact on the content of total sugars, as well as the reducing sugars compared to the control object (on which growth biostimulators and herbicide were not applied). The value of these characteristics depended only on the course of weather conditions in the years of research. More total sugars were collected by tubers in a warm and dry growing season of 2015 while reducing sugars - in humid and cool growing season of 2017. 


\section{REFERENCES}

[1] Amrein, T. M., Schönbächler, B., Rosner, F. (2004): Potential for acrylamide formation in potatoes: data from the 2003 harvest. - Eur. Food Res. Technol. 219: 572-578.

[2] Baranowska, A., Zarzecka, K., Gugała, M., Mystkowska, I. (2017): Contents of zinc, copper and manganese in potato tubers depending on the ways of application of the soil fertilizer $U_{\text {max }}$ - Journal of Ecological Engineering 18(1): 99-106.

[3] Bhattacharjee, A., Roy, T. S., Haque, M. N., Pulok, M. A. I., Rahman, M. M. (2014): Changes of sugar and starch levels in ambient stored potato derived from TPS. International Journal of Scientific and Research Publications 4: 1-5.

[4] Biedermann-Brem, S., Noti, A., Grab, K. (2003): How much reducing sugar may potatoes contain to avoid excessive acrylamide formation during roasting and baking? - Eur. Food Res. Technol. 217: 369-373.

[5] Brazinskiene, V., Asakaviciute, R., Miezeliene, A., Alencikiene, G., Ivanauskas, L., Jakstas, V., Viskeli, P., Razukas, A. (2014): Effect of farming systems on the yield, quality parameters and sensory properties of conventionally and organically grown potato (Solanum tuberosum L.) tubers. - Food Chemistry 145: 903-909.

[6] Bulgari, R., Cocetta, G., Trivellini, A., Vernieri, P., Ferrante, A. (2015): Biostimulants and crop responses: a review. - Biological Agriculture \& Horticulture 31(1): 1-17.

[7] Calvo, P., Nelson, L., Kloepper, J. W. (2014): Agricultural uses of plant biostimulants. Plant Soil 383: 3-41.

[8] Camire, M. E., Kubow, S., Donnelly, D. J. (2009): Potatoes and Human Health. - Critical Reviews in Food Science and Nutrition 49: 823-840.

[9] Chereszkowicz, E. (1979): Agricultural Climatic Resources of the Territory of Socialist Countries in Europe (in Germany). - Sofia.

[10] Copp, L. J., Blenkinsop, R. W., Yada, R. Y., Marangoni, A. G. (2000): The relationship between respiration and chip colour during long-term storage of potato tubers. - Am. J. Potato Res. 77: 279-287.

[11] De Wilde, T., Meulenaer, B., Mestdagh, F., Govaert, Y., Ooghe, W., Fraselle, S. (2006): Selection criteria for potato tubers to minimize acrylamide formation during frying. $-\mathrm{J}$. Agric. Food Chem. 54(6): 2199-2205.

[12] Du Jardin, P. (2012): The Science of Plant Biostimulants - A Bibliographic Analysis. Ad hoc Study Report to the European Commission DG ENTR.

[13] Ezekiel, R., Singh, N., Sharma, S., Kaur, A. (2013): Beneficial phytochemicals in potato a review. - Ford Research International 50: 487-496.

[14] Finlay, M. B., Bradshaw, D., Bradshaw, J. E. (2003): Progress in improving processing attributes in potato. - Trends in Plant Science 8: 310-312.

[15] Frydecka-Mazurczyk, A., Zgórska, K. (2002): Impact of autumn tuber overcooling on the contents of glucose, fructose and sucrose (in Polish). - Zeszyty Problemowe Postępów Nauk Rolniczych 481: 141-146.

[16] Grudzińska, M., Zgórska, K. (2008): Impact of the content of sugars in tubers of potato on the colour of potato chips (in Polish). - Żywność. Nauka. Technologia. Jakość 5(60): 107-115.

[17] Grudzińska, M., Zgórska, K. (2010): Impact of efficiency of the reconditioning treatment of selected varieties of potato tubers on the colour of french fries (in Polish). - Nauka. Przyroda. Technologie 4(2): 17-25.

[18] Grudzińska, M., Zgórska, K., Czerko, Z. (2014): Impact of meteorological conditions on the content of reducing sugars in potato tubers (in Polish). - Zeszyty Problemowe Postępów Nauk Rolniczych 577: 43-52.

[19] Grudzińska, M., Czerko, Z., Wierzbicka, A., Borowska-Komenda, M. (2016): Changes in the content of reducing sugar and sucrose in tubers of 11 potato cultivars during longterm storage at 5 and $8{ }^{\circ} \mathrm{C}$ (in Polish). - Acta Agrophysica 23: 31-38. 
[20] Grużewska, A., Zarzecka, K., Gugała, M., Paprocka, S. (2016): The importance of production and consumption of potato and oilseed rape in Poland and selected EU countries (in Polish). - Zeszyty Naukowe Szkoły Głównej Gospodarstwa Wiejskiego. Problemy Rolnictwa Światowego 2(16): 85-93.

[21] Gugała, M., Zarzecka, K., Sikorska, A., Dołęga, H. (2013): Changes in sugar content in cultivars potato tubers depending on the weed control methods (in Polish). - Progress in Plant Protection 53: 271-275.

[22] Hebeisen, T., Ballmer, T., Guthapfel, N., Torche, J. M., Reust, W. (2005): Suitable potato varieties reduce acrylamide formation in processed products and disher. -16 th Triennial Conference of the European Association for Potato Research, July 17-22, Bilbao, Spain. 496-500.

[23] Jarych, M. (2004): Changes of carbohydrate compounds content in potato tubers, depending on variety and doses of nitrogen. - Żywność 3(40): 98-107.

[24] Krełowska-Kułas, M. (1993): Test the Quality of Food Products (in Polish). - Państwowe Wydawnictwo Ekonomiczne, Warszawa.

[25] Maciejewski, T., Szukała, J., Jarosz, A. (2007): Influence of biostimulant Asahi SL and Atonik SL on qualitative tubers of potatoes (in Polish). - Journal of Research and Applications in Agricultural Engineering 52: 109-112.

[26] Matyjaszczyk, E. (2015): Introduction of Biostimulators for Trade in Poland. The Current Situation and Legal Considerations (in Polish). - Przemysł Chemiczny 94(10): 18411844.

[27] Mojska, H., Gielecińska, I., Marecka, D., Kłys, W. (2008): Research on the influence of raw material components and technological factors on the level of acrylamide in potato french fries (in Polish). - Roczniki Państwowego Zakładu Higieny 52(2): 163-172.

[28] Murniece, I., Karklina, D., Galoburda, R., Santare, D., Skrabule, I., Costa, H. S. (2011): Nutritional composition of freshly harvested and stored Latvian potato (Solanum tuberosum L.) varieties depending on traditional cooking methods. - J. Food Com. Anal. 24: 699-710.

[29] Navarre, D. A., Goyer, A., Shakya, R. (2009): Nutritional Value of Potatoes: Vitamin, Phytonutrient, and Mineral Content. - In: Singh, J., Kaur, L. (eds.). Advances in Potato Chemistry and Technology. Academic Press, Elsevier, Cambridge, MA.

[30] Nourian, F., Ramaswamy, H. S., Kushalappa, A. C. (2003): Kinetics of quality change associated with potatoes stored at different temperatures. - Lebensm. - Wiss. U. Technol. 36: 49-65.

[31] Plant Breeding and Acclimatization Institute - National Research Institute (2017): Characteristics of the Polish National Register of Cultivars (in Polish) Issue XX. - IHAR, Jadwisin.

[32] Rodriguez, Galdon, B., Rios, Mesa, D., Rodriguez, E. M., Diaz, Romero, C. (2010): Influence of the cultivar on the organic acid and sugar composition of potatoes. - J. Sci. Food Agric. 90: 2301-2309.

[33] Rudzińska-Mękal, B. (2000): Modifying the Chemical Composition of Potato Tubers by Synthetic Growth Regulators Mival and Moddus 250 ME (in Polish). - Typescript of a Dissertation. Wydział Rolniczy. Akademia Rolnicza w Lublinie.

[34] Sawicka, B., Pszczółkowski, P. (2005): Dry matter and carbohydrates content in the tubers of very early potato varieties cultivated under coverage. - Acta Sci. Pol., Hortorum Cultus 4(2): 111-122.

[35] Skowera, B. (2014): Changes of hydrothermal conditions in the Polish area (1971-2010) (in Polish). - Fragmenta Agronomica 31(2): 74-87.

[36] Storey, R. M. J. (2007): The Harvested Crop. - In: Vreugdenhil, D. (ed.) Potato Biology and Biotechnology Advances and Perspectives. - Elsevier, Amsterdam.

[37] Trawczyński, C. (2014): Impact of amino acid biostimulators - tecamin on the crop and quality of potato (in Polish). - Ziemniak Polski 3: 29-34. 
[38] Wegener, C. B., Jansen, G., Jürgens, H. U. (2015): Bioactive compounds in potatoes: Accumulation under drought stress conditions. - Functional Foods in Health and Disease 5(3): 108-116.

[39] Wójcik-Stopczyńska, B., Grzeszczuk, M., Jakubowska, B. (2012): The content of some and potentially harmful nutrients in edible potatoes from the commercial network (in Polish). - Roczniki Państwowego Zakładu Higieny 63(2): 207-212.

[40] Zarzecka, K., Gugała, M. (2018): The effect of herbicides and biostimulants on sugars content in potato tubers. - Plant Soil Environmental 64(2): 82-87.

[41] Zarzecka, K., Gugała, M., Zarzecka, M. (2013): Potato as good source nutrients (in Polish). - Postępy Fitoterapii 3: 191-194.

[42] Zarzecka, K., Gugała, M., Mystkowska, I., Baranowska, A., Sikorska, A. (2017): Effect of herbicides on the content dry matter and sugars in edible potato tubers. - Romanian Agricultural Research 34: 2067-5720.

[43] Zgórska, K. (2013): The use of potato for food and industrial applications (in Polish). Inżynieria Przetwórstwa Spożywczego 3(4): 5-9.

[44] Zgórska, K., Grudzińska, M. (2012): Changes in the selected quality characteristics of potato tubers during storage (in Polish). - Acta Agrophysica 19(1): 203-214.

[45] Zgórska, K., Sowa-Niedziałkowska, G. (2005): The influence of thermal and varietal factor on the quality changes occurring in potato tubers during their long term storage (in Polish). - Pamiętnik Puławski 139: 327-336.

[46] Ziosi, V., Zandoli, R., Di Nardo, A. (2013): Biological activity of different botanical extracts as evaluated by means of an array of in vitro and in vivo bioassays. - Acta Hortic. 1009: 61-66.

[47] Żyżlewicz, D., Nebescy, E., Oracz, J. (2010): Acrylamide - formation, physico-chemical and biological properties (in Polish). - Bromat. Chem. Toksykol. 3: 415-427. 